\title{
Demographic Shifts Influencing the Political Landscape of the Lake Victoria Basin in Uganda
}

\author{
Fredrick Ruguma Tumwine*, Yazidhi Bamutaze, Hosea Opedes
}

Department of Geography, Geo-informatics \& Climatic Sciences, Makerere University, Kampala, Uganda

Copyright $\mathrm{O} 2018$ by authors, all rights reserved. Authors agree that this article remains permanently open access under the terms of the Creative Commons Attribution License 4.0 International License

\begin{abstract}
High population growth in Uganda is associated with substantial reduction in Infant and Child mortality without commensurate reduction in fertility. Kampala city $(100 \%$ urban) and Wakiso district $(59 \%$ urban) are densely populated with 9,429 and 1,100 people per square $\mathrm{km}$ respectively (UBOS [1]). The paper explains strong links between high population growth rate of $3.03 \%$ / annum, high rate of urbanization (5.1\% / annum) one of the major demographic shifts in the country and the changing political landscape of Kampala City and Wakiso district. The paper utilizes both primary and secondary data. Time series gridded population density data was obtained from the Center for International Earth Science Information Network (CIESIN) database and processed in ArcGIS 10.1 program. Change detection analysis for three periods; 2000, 2010 and 2015 was conducted to determine the spatial and temporal patterns of population density in the Lake Victoria Basin. Primary data was obtained from in-depth interviews. Secondary population data was obtained from Uganda Population and Housing Census results (UPHC) 1991, 2002 and 2014; and Uganda Presidential Election results of 2001, 2006, 2011 and 2016. Results based on the imagery analysis of the gridded data reveals increasing concentration and hotspot of population density in the Lake Victoria Basin signifying it not only an economic center but also a political hotspot region. The paper reveals that high population growth rate and urbanization have influenced dependency ratio, unemployment, underemployment, poverty, standards of social services and infrastructure as well as political landscape and ramblings. It explains why the National Resistance Movement (NRM) ruling party despite its national strength performs poorly in the urban areas as compared to opposition led by Forum for Democratic Change (FDC). The paper recommends fast tracking the establishment of Kampala metropolitan area, consultative development planning that balances economic and environmental concerns and emphasizing urban development as opposed to creation of new districts.
\end{abstract}

Keywords High Population Growth, Urbanization, Demographic shifts, Political Landscape, Lake Victoria
Basin

\section{Introduction}

Uganda has one of the youngest populations in the world with nearly half of them aged below 15 years. However, in the last decade population growth rate reduced from $3.2 \%$ per annum in the period 1991-2002 to $3.03 \%$ / annum during 2002-2014 period due to the continued decline in mortality and a slight decline in fertility as observed from Table 1.

National Population Council forecasts Uganda's population to grow to 47 million by 2025 and 63 million by 2030 (Ggoobi [2]). The major population characteristics of Uganda include: declining family size, falling fertility and mortality rates, improved literacy levels and increasing life expectancy but growing levels of unemployment (UNFPA [3]).

Uganda is on the verge of demographically shifting from the second stage of the demographic transition to the third stage. According to Table 1, the average number of children produced per woman fell to six (TFR 6.2) from seven that had persisted for the last 45 years (1969 to 1979) despite the continuous fall of mortality in the same period. As a result of the farther decline in fertility to five children in 2017 (TFR 5.4) from six in 2014 (TFR 6.2) and un interrupted decline in mortality as observed from the mortality measures the gap between fertility and mortality has started to narrow down and therefore the slight decline in the growth rate from $3.2 \%$ to $3.0 \%$, hence showing characteristics of the third stage of demographic transition. Increase in full immunization has led to reduction in infant and child mortality. While on the other hand, increase in school enrolment due to Universal Primary Education (UPE) and Universal Secondary Education (USE) and urbanization coupled with increased contraceptive prevalence have led to the reduction of fertility. This is more exemplified in the urban areas where TFR was 4.1 as compared to 7.4 in the rural areas in 2002 and 3.8 and 6.8 respectively in 2012 (Tumwine \& Ntozi [4]). 
Table 1. Selected population indices of Uganda from 1969 to 2017

\begin{tabular}{|c|c|c|c|c|c|c|c|c|c|c|}
\hline Time period (Years) & 1969 & 1988 & 1991 & 1995 & 2000 & 2002 & 2006 & 2010 & 2014 & 2017 \\
\hline Total Fertility Rate (TFR) & 7.4 & 7.3 & 7.1 & 6.9 & 6.9 & 6.9 & 6.7 & 6.5 & 6.2 & 5.4 \\
\hline Contraceptive use (\%) & - & 5 & - & 15 & 23 & 23 & 23.7 & 24 & 30 & 39 \\
\hline Infant Mortality (per 1000) & - & 122 & 122 & 81 & 88 & 82 & 76 & 54 & 54 & 43 \\
\hline Child Mortality (per 1000) & - & - & 180 & 147 & 152 & 141 & 137 & 90 & 69 & 64 \\
\hline Full immunization coverage (\%) & - & - & 31 & 47 & 38 & 63 & 46 & 52 & - & 97 \\
\hline Average annual growth rate (\%) & 3.9 & - & 2.5 & - & - & 3.2 & - & - & 3.0 & - \\
\hline
\end{tabular}

Sources:(UBOS [1], UBOS [2], UBOS [7], Kaijuka [8] and Ministry of Finance and Economic Planning [9]).

High population growth rates compete with the growth rate of household incomes. Increase in the population cancels out the increase in aggregate output which keeps average incomes low and stagnant thus keeping people in the vicious cycle of poverty (Ggoobi [2]). High population growth rate is characterized by very low production increases the Marginal Propensity to Import (MPM). The MPM measures the response of imports to Domestic Income (GDP). In 2016, the MPM for Uganda stood at $33 \%$. This implies that about $33 \%$ of each extra shilling earned by Ugandans was shipped out of the country to countries that produce Uganda's imports. These include: China, India, Kenya, South Africa, South Korea, Malaysia etc. To make matters worse, Uganda's population is characterized by low levels of savings and capital accumulation. Ugandans have a culture of consumerism. They love to live luxurious and ostentatious styles: hang out in eateries and consume sumptuous meals and alcohol, holding parties, weddings and fanfare. Some go to the extent of borrowing to finance these ostentatious lifestyles (Ggoobi [2])

Uganda's youthful population is majorly unskilled or semi-skilled and not financially empowered as well. This leads to low participation of Ugandan nationals in the market economy. The few that are engaged in the market economy are concentrated mainly in small, informal business majorly vending products that foreigners produce. The big time investors are involved in non-tradable items mainly construction of shopping malls, apartments and land. Since these are not exported, their multiplier effect is low. The large and thriving businesses such as telecommunications, banking, large scale manufacturing and wholesale are foreign owned and thus repatriation of profits (Ggoobi [2])

Urbanization is arguably the most dramatic form of irreversible land transformation. It may be linked with details of topography, transportation, land use, social structure and economic type, but it is generally related to demography and economy (Taubenbock et al. [9]). While urbanization is a worldwide phenomenon, in Uganda one should consider the political and economic dimensions. Dennis (10) findings indicate that between 2002 and 2009, $20 \%$ of the aggregate growth in labor productivity in Uganda reflected the drifting towards industries and sectors where it was more productive on average and at the margin. In addition, given that there is low productivity in agriculture, relocation of workers from the sector to other sectors (industries and services) impacts on per capita growth and employment positives. This has culminated to rural urban migration of young educated people seeking for employment more especially in Kampala and the surrounding urban areas of Wakiso district.

The population of the world is on the verge of shifting from being predominantly rural to urban. As of 2008, more than half of the world's human population resided in urban areas and by 2030, urban inhabitants will account for approximately $60 \%$ of the world's population (Pham et al. [11]). The rapid growth of the urban population has occurred in response to increased urban migration as people search for better jobs and improved living conditions. Historically, urban immigration has exceeded those of infrastructure development in the destination cities, resulting in immigrants being unable to find suitable employment opportunities and subsequently becoming increasingly for city planners to adopt appropriate sustainable land use plans. In Uganda, the high population growth rate and urbanization have led to high dependency ratio, unemployment, underemployment, poverty, low standards of social services and infrastructure as well as influencing the political landscape that is always associated with ramblings. Planning and managing urban spaces depends on knowledge of the underlying driving forces, combined with the chronology and impacts of urbanization (Pham et al. [11]).

The level of urbanization in Uganda has been increasing steadily. The urban population and proportion increased from $634,952(6.9 \%)$ in 1969 , to $938,287(7.4 \%)$ in 1980 , $1,889,662(11.3 \%)$ in $1991,2,921,981(12.3 \%)$ in 2002 and $6,424,013(18 \%)$ in 2014 (UBOS [8]). This increase is partly because of natural population increase, an increase in the number of urban centers from 75 in 2002 to 259 (01 City, 33 Municipalities, 163 Town Councils and 62 Town Boards/ Townships) in March 2016 and expansion in the geographical area of some urban centers. Kampala city has remained the primate urban center throughout the period 1991-2014 with $41 \%$ of urban population in 1991 and $25 \%$ in 2014 (UBOS [8]).

Kampala City (100\% urban) had a population of 1.5 
million and Wakiso district which neighboring Kampala (59\% urban) had 2 million (UBOS [8]). This implies that Kampala City and Wakiso district make $10 \%$ of Uganda's population and with an upward trajectory. City planners, economists and resource managers therefore need advanced methods and a comprehensive knowledge of the cities under their jurisdiction to make informed decisions necessary to guide sustainable development to cater for the rapidly changing urban environments.

Although rapid urbanization brings opportunities to new urban developments, it also comes with serious loss of ecosystems and degradation of arable land as well as social and environmental changes to urban populations, if the planning does not match with the changing situation. Unplanned population growth and massive rural-urban migration have also contributed to environmental degradation. Development of physical infrastructure has been promoted at the expense of ecological infrastructure. Hence there is need for local urban authorities to practice environmentally sustainable urban development where improvement of the quality of life in a city, includes ecological, cultural, political, institutional and economic components without leaving a burden on future generations. There is need to conserve existing ecosystems like wetlands in which ecological services are improved so that people can enjoy nature, including clean air and water, and even listen to birds sing beautifully (Kahangirwe [13]). For example, in twenty six years, state protected forest cover reduced by $61.2 \%$ and wetland coverage reduced by $44 \%$. Specifically, forest cover reduced from 4.9 million hectares in 1990 to 1.9 million hectares in 2015, at a rate of 120,000 hectares per year (Kwesiga [14]).

Lake Victoria basin is one of the most densely populated and urbanized areas in East Africa. Thus, urban centers in the Lake Victoria Basin, notably Kampala City and Wakiso district in Uganda have been experiencing increasing population densities due the relatively conducive economic conditions compared to other areas. As a result of the high population and density, the region is a hot political spot for both the ruling National Resistance Movement (NRM) and the opposition led by Forum for Democratic Change (FDC) and Democratic Party (DP). A spatial configuration of the population dynamics is thus a key ingredient in the political discourses and contestations of the major actors and parties. Geospatial tools and analytics provide spatially consistent coverage of large areas with both high spatial detail and temporal frequency, which are useful for examining historical time series. Overtime, availability of geospatial data for change detection in a range of fields has grown and gives greater opportunities for dynamic assessments. With increased availability and improved multi-spatial and multi-temporal resolution coupled with availability of archived or semi-processed remotely sensed data, geospatial analytics can now be applied to monitor and analyze urban expansion and land use change in a timely and cost effective manner (Pham et al. [11]). Population growth is a dynamic phenomenon which not only impacts on the natural environment but has implications on the spatial aspects of political discourse especially in developing countries. The gist of this study was to assess the demographic shifts and its influence on the political landscape in two urban areas in the Lake Victoria Basin of Uganda. The study was more focused on the electoral dynamics and voting patterns spanning a period of 2001 to 2016 that coincides with reasonable data availability on vote scores of major parties in Uganda.

\section{Materials and Methods}

\section{Study Area}

The study was conducted in Kampala city and Wakiso District, which are part of the lake Victoria Basin of Uganda. Kampala is the capital city of Uganda, but is geographically encircled by Wakiso District as shown in Figure 1. While Kampala city is almost purely urban, Wakiso district has both the rural and urban extremes. A high degree of geographical and economic connectivity exists between the two entities with most people residing in Wakiso district but working in Kampala city. Consequently, there is a high degree of social, economic, political and environmental interactions between the two entities. Wakiso district is about 10 times larger than Kampala city. The area coverage for Wakiso district and Kampala city is $1907 \mathrm{~km}^{2}$ and $189 \mathrm{~km}^{2}$ respectively. The average elevation for Wakiso District and Kampala city is 1200 and 1190 meters above sea level respectively.

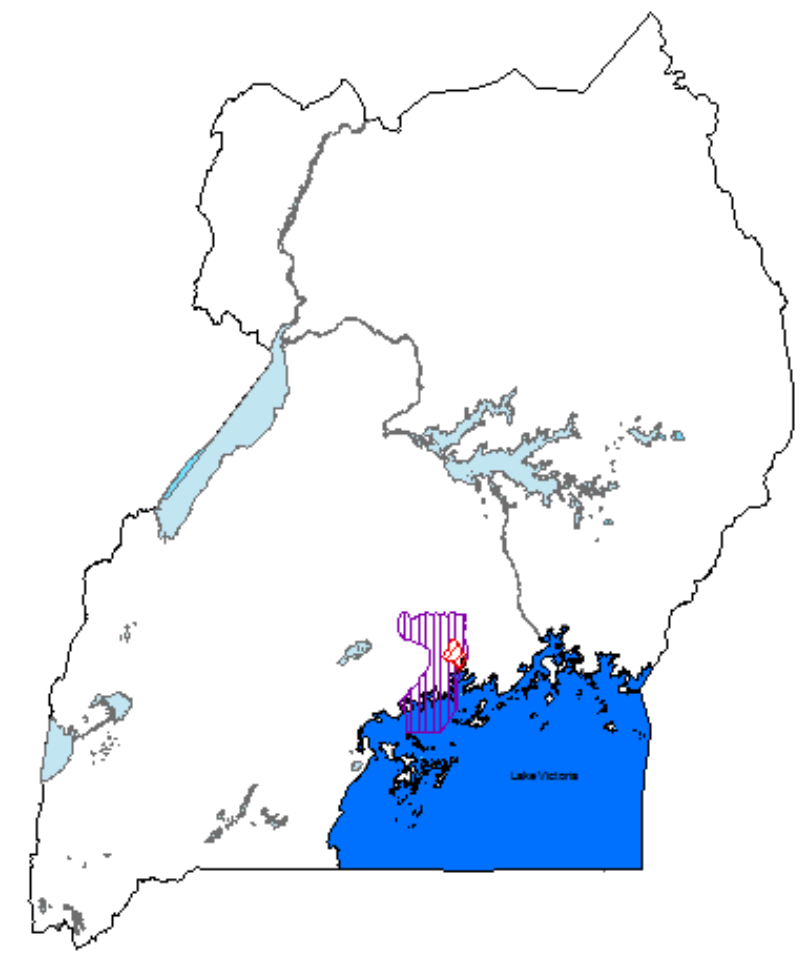




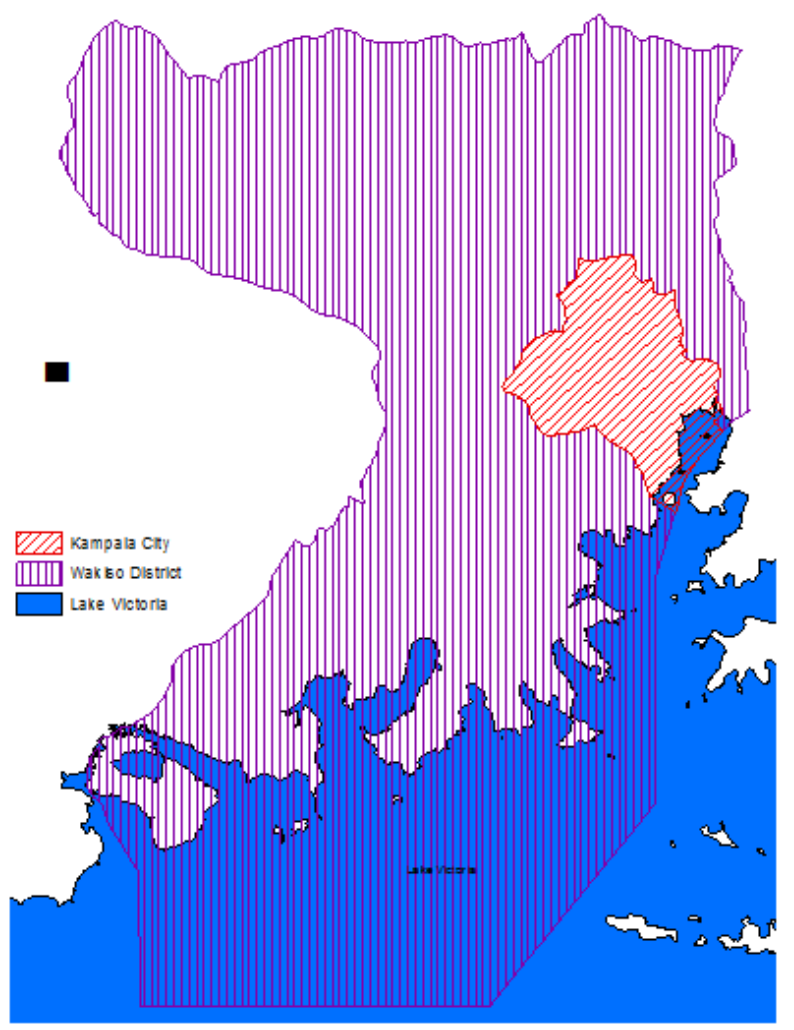

Figure 1. Location of the study area

\section{Methods}

The study utilizes both primary and secondary data. Primary data was obtained from in-depth interviews. Secondary population data was obtained from Uganda Population and Housing Census results (UPHC) 1991, 2002 and 2014; and Uganda Presidential Election results of 2001, 2006, 2011 and 2016. Time series data on population and electoral votes was obtained from the Uganda Bureau of statistics (UBOS) and the Electoral Commission of Uganda. For spatial analysis, gridded population data for three periods i.e. 2000, 2010 and 2015 was obtained from the Center for International Earth Science Information Network (CIESIN). The gridded population density data in raster format is provided at 1 kilometer resolution and was processed in ArcGIS 10.1 program. The data was obtained at the continental and the appropriate layers for the three periods were clipped out to the national scale for ease of visualization. Visualization and computations of changes were implemented in a GIS environment. Simple arithmetic computations were undertaken to decipher quantitative changes in the population density.

\section{Results}

\section{Population Changes in Kampala City and Wakiso District}

Kampala city and Wakiso district were chosen as case studies because of the following reasons: Kampala is the only city in Uganda and at the same time, it is the capital and the largest urban area in the country. It has remained a prime urban center from 1969 to 2014 . In $1969,54 \%$ of the urban population resided in Kampala, 1991 (41\%), 2002 (40\%) and 2014 (25\%). On the other hand, Wakiso district had four out of the 20 largest urban areas in Uganda between 2002 and 2014. As observed from Table 2 these included: Nansana Town council $\left(2^{\text {nd }}\right)$; Kira Town Council $\left(3^{\text {rd }}\right)$; Makindye - Ssabagabo $\left(4^{\text {th }}\right)$ and Entebbe Municipality $\left(19^{\text {th }}\right)$ (UBOS [8])

Table 2. Population of the 20 largest Urban Centers, 1991 - 2014

\begin{tabular}{|c|c|c|c|c|c|}
\hline Rank & District & Urban centre & Population 2014 & Population 2002 & Population 1991 \\
\hline 1 & Kampala & Kampala Capital City & $1,507,114$ & $1,189,142$ & 774,241 \\
\hline 2 & Wakiso & Nansana Municipality & $\mathbf{3 6 5 , 8 5 7}$ & na & na \\
\hline 3 & Wakiso & Kira Municipality & 317,428 & na & na \\
\hline 4 & Wakiso & Makindye-Ssabagabo & 282,664 & na & na \\
\hline 5 & Mbarara & Mbarara Municipality & 195,180 & 69,363 & 41,031 \\
\hline 6 & Mukono & Mukono Municipality & 162,744 & 46,506 & 7,406 \\
\hline 7 & Gulu & Gulu Municipality & 149,802 & 119,430 & 38,297 \\
\hline 8 & Buikwe & Lugazi Municipality & 114,163 & 27,979 & 18,828 \\
\hline 9 & Masaka & Masaka Municipality & 103,293 & 67,768 & 49,485 \\
\hline 10 & Kasese & Kasese Municipality & 101,557 & 53,907 & 18,750 \\
\hline 11 & Hoima & Hoima Municipality & 100,126 & 27,934 & 4,616 \\
\hline 12 & Lira & Lira Municipality & 99,511 & 80,879 & 27,568 \\
\hline 13 & Mityana & Mityana Municipality & 96,075 & 34,116 & 22,579 \\
\hline 14 & Mubende & Mubende Municipality & 95,416 & 15,996 & 9,301 \\
\hline 15 & Masindi & Masindi Municipality & 94,439 & 28,300 & 10,839 \\
\hline 16 & Mbale & Mbale Municipality & 92,863 & 71,130 & 53,987 \\
\hline 17 & Jinja & Jinja Municipality & 76,057 & 71,213 & 65,169 \\
\hline 18 & Kitgum & Kitgum Municipality & 75,594 & 41,821 & 12,978 \\
\hline 19 & Wakiso & Entebbe Municipality & 69,430 & 55,086 & 42,763 \\
\hline 20 & Buikwe & Njeru Town Council & 68,835 & 51,236 & 36,731 \\
\hline
\end{tabular}

Source: (UBOS [8]) Page 11 
The spatial configuration of the population density in 2000, 2010 and 2015 for the entire country is illustrated in Figure 2. At the national level, the highest population densities are found in the Lake Victoria Basin and the highland regions. Urban centers in the Lake Victoria Basin of the country have developed relatively more rapidly than other areas. This puts them in vantage positions on a range of aspects including the political discourse. It can clearly be visualized that Kampala city and Wakiso district are population density hotspots and exhibit pronounced increments between 2000 and 2015.

\section{Political Landscape of Kampala City and Wakiso District}

While the National Resistance Movement party (NRM) has always won with overwhelming majority at national level and the rural areas. The opposition led by Forum for Democratic Change (FDC) has enjoyed the support of urban areas led by Kampala and Wakiso district. This concurs with (Mwenda [15]) that during the 2016 elections:
"Besigye's strength is questionable. His party fielded parliamentary candidates in only 201 of the 290 geographical constituencies, 61 out of 112 positions for woman MP, 43 out of 112 district chairpersons, 536 out of 1,403 sub-county chairperson positions, 1,123 candidates against NRM's 6,663 in sub-county women councilors, 2,049 candidates against 7,303 in sub-county positions".

Despite the unprecedented rate of urbanization around the world, information regarding land use planning and management is not updated frequently enough to accurately track this urban change (Pham et al. [11]). UNFPA (16) observes that as the urban population increases, more social services need to be put in place such as schools, hospitals, water, security personnel, recreational facilities and others. In case of Uganda, this has not been the case to a large extent. This explains why Kampala City and Wakiso district have been good harvesting grounds for votes in favor of the opposition as observed in Table 3, Figure 3 and the discussions that follow:

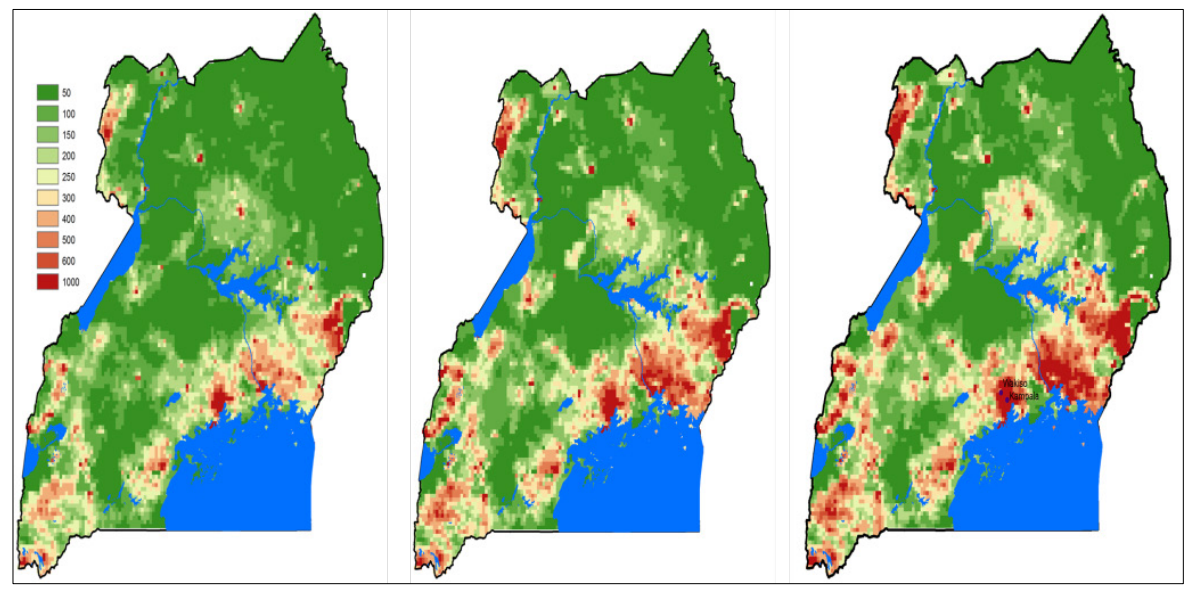

Figure 2. The population density trends for the three census years (2000, 2010 and 2015) in Uganda

Table 3. Election results for Kampala City and Wakiso district

\begin{tabular}{|c|c|c|c|c|c|}
\hline \multirow{2}{*}{ Year } & Electoral Area & NRM (\% votes) & FDC (\% votes) & $\begin{array}{c}\text { Other Parties / } \\
\text { Candidates (\% votes) }\end{array}$ & Total \\
\hline \multirow{2}{*}{2001} & Kampala & 47.5 & 50.2 & 2.3 & 1.4 \\
\cline { 2 - 6 } & Wakiso & 51.4 & 47.2 & 5.8 & 100.0 \\
\hline \multirow{2}{*}{2006} & Kampala & 39.5 & 56.7 & 5.8 & 100.0 \\
\cline { 2 - 7 } & Wakiso & 47.7 & 46.5 & 7.3 & 100.0 \\
\hline \multirow{2}{*}{2011} & Kampala & 46.1 & 46.6 & 8.6 & 100.0 \\
\cline { 2 - 7 } & Wakiso & 49.3 & 42.1 & 3.2 & 100.0 \\
\hline \multirow{2}{*}{2016} & Kampala & 30.9 & 65.9 & 3.2 & 100.0 \\
\cline { 2 - 7 } & Wakiso & 36.8 & 60.0 & & 100.0 \\
\hline
\end{tabular}




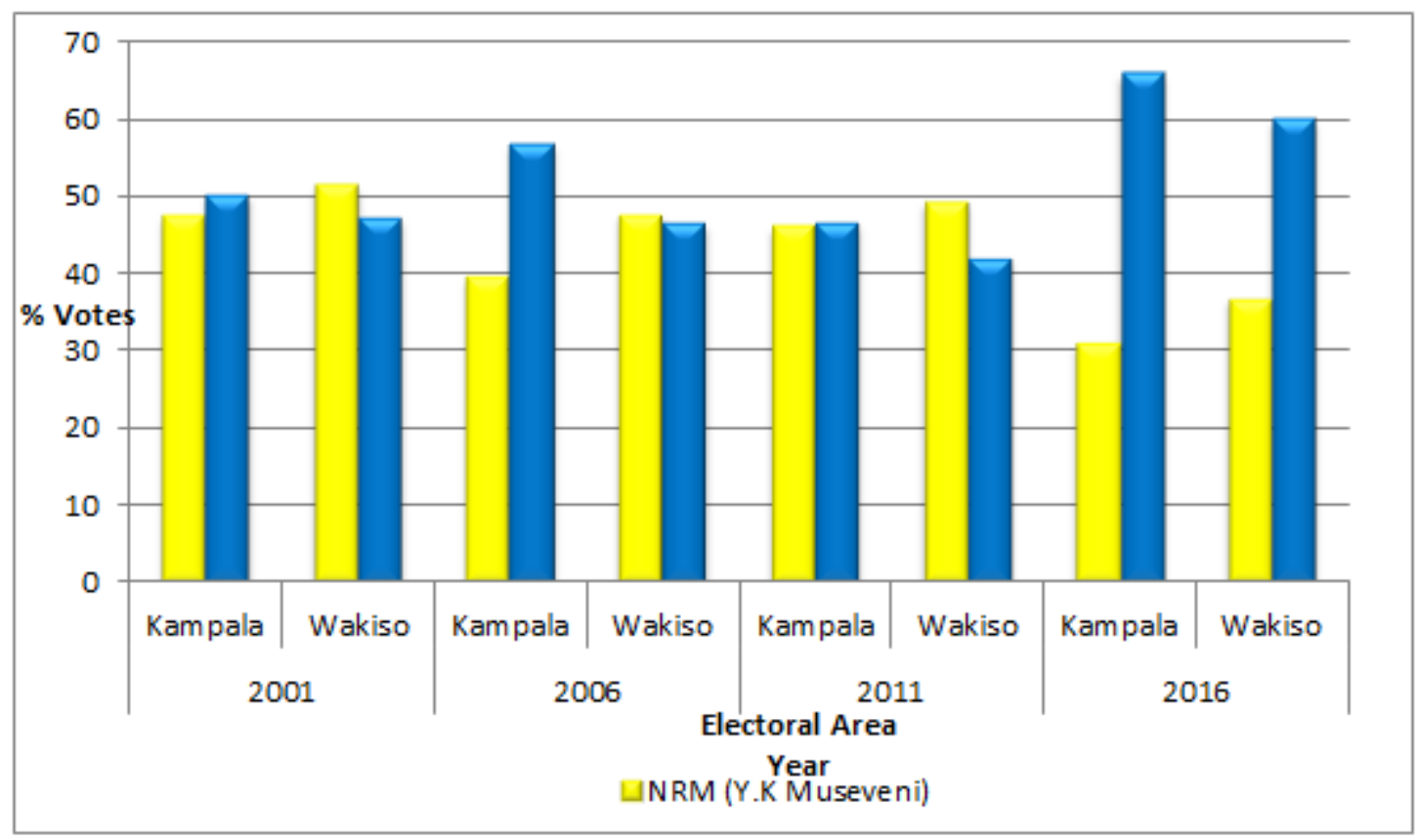

Figure 3. Performance of presidential candidates in Kampala City and Wakiso district 2001-2014

Garbage management is one of the factors that have affected the voting patterns of the urban duelers. Despite interventions through community sensitization, and addressing inefficiencies in fleet management; solid waste collection had increased from 140,000 tons per years in 2011 to 360,000 tons per year in 2013. The generation of solid waste in Kampala is estimated at 730,000 tons per year, implying that only 50 percent is collected and properly disposed of. The un-collected waste is dumped indiscriminately - most of it ends in drainage channels, which drains into Lake Victoria. One of the key informants remarked: "Why should I vote for NRM which has failed to collect the garbage? The city stinks".

Up to 70 percent of the waste generated is organic, which increases pollution load into Lake Victoria and creates a stinking smell in many areas. Environmental experts also argue that non-organic portion of solid waste comprise non-degradable materials that lead to clogging of drainage channels and destabilization of ecological processes in the wetlands, buffering Lake Victoria. The experts further say waste and silt deposition in the drains also reduce storm water carrying capacity, resulting into frequent flooding, loss of livelihoods and spread of communicable diseases. According to Kampala Physical Development Plan (KPDP) 2013 Kampala City is undergoing rapid socio-economic and physical transformation with a population likely to reach over eight million by 2040 with huge implication on waste management. To make matters worse, the garbage collection site located in Kitezi, Wakiso district is not well managed as evidenced by the smell in the area. Residents of the area are always complaining of the smell and vote for the opposition expecting it to correct the anomaly. One of the Key Informants remarked about Kitezi: "The smell from the site makes our stomachs rumble, our water source has been contaminated, our animals have died"

Traffic jam is yet another thorn for the ruling party NRM. For example, one of the key informants commented: " $A$ family that resides in Kira says they take three hours to reach office in the morning and another three to reach home in the evening" But traffic congestion is more than irritating jam. A World Bank study says those traffic jams are costing Uganda over $\$ 800$ million (over sh2.8 trillion) in Gross Domestic Product (GDP). As of 2014, Uganda's vehicle population was over 500,000 and that the country was adding 10,000 more cars annually. A big number of these are commuter taxis (Mugisa [17]). Tax operators have been resisting introduction of buses for fear of losing jobs. This is because a bus takes 64 passengers that can be transported by 4 commuter taxis that carry 14 passengers each.

Street vendors who sell same items like those sold in the shops are another voting bloc in urban areas. When the vendors are evicted from the streets to make the city streets less congested and allow shop traders to operate without obstruction, they vote the opposition candidate. Kitubi et al. [18] note that the vendors get the items from some of the whole sellers in some of the shops. They sell the items at a lower price. The traders renting shops in arcades pay for trading licenses, income tax, electricity, water and garbage collection, while the street vendors do not. The policy of KCCA is that every arcade should have parking lots, but vendors take over the parking lots, a move that turns away customers according to the traders. The traders in the shops are being driven from business. The issue is political. The street vendors claim they were allowed by president Museveni. That only Museveni can tell them to leave the streets. They claim they have small capital and therefore 
should be allowed to remain on the streets. Some of them were working in the markets but left their stalls. They claim customers who visit the markets are few. Some suggest that they be allowed to work in the evenings 5.00 to $10.00 \mathrm{pm}$. They had been allowed to operate on Sundays under the open market initiative. It has also been proposed that KCCA closes off Luwum and Market streets to allow vendors sell their products. Kampala City Traders Association (KACITA) also wants that stopped. The Lord Mayor supports vendors. On the $17^{\text {th }}$ October 2016, KACITA gave the vendors an ultimatum to leave the streets. The Government ordered them off the streets effective Thursday, $20^{\text {th }}$ October 2016. It is believed that when the vendors were made to vacate the streets, they voted against the ruling party (NRM).

A number of low income traders operate along road and rail reserves. In 2015, kiosks and houses on road and railway reserves were destroyed in Kampala to make the City clean. However, this was resisted after Banda located in Wakiso district, East of Kampala city. The owners of the property argued that KCCA had no authority in Wakiso district. The drive by KCCA to clean up the city by evicting micro -business without providing good alternative business centers was criticized because it was believed to lead to loss of many businesses that could have grown into tomorrow small and medium scale multi-national corporations. A number of respondents were of the view that Government should promote local enterprises by providing business safe havens and incubation centers for the emerging micro-enterprise to complement and provide services to the large corporations (UNFPA, [3]). While the middle and high class welcomed the clean-up, the people affected and the urban poor majority did not like it. This is believed to have been one of the main reasons they voted against the ruling party (NRM). President Museveni admitted this after the elections when he said, "KCCA used excessive force to evict traders."

Motorcycle (boda-boda) transport is another thorn in Kampala city. Some of the riders do not have riding permits; they do not follow traffic laws and regulations. They are extremely many. They overload. A motorcycle can carry four passengers (Figure 4). They are the main causes of accidents. Some of them are either criminals or are used by criminal elements to cause mayhem in the city and its suburbs. The number of boda-boda operators has continued to grow in the city and its suburbs thereby reducing the profitability of the business. KCCA tried without success to organize the boda-boda business. This was interpreted to imply that the government wanted to stop them from operating from the city rendering a good number to vote for the opposition.

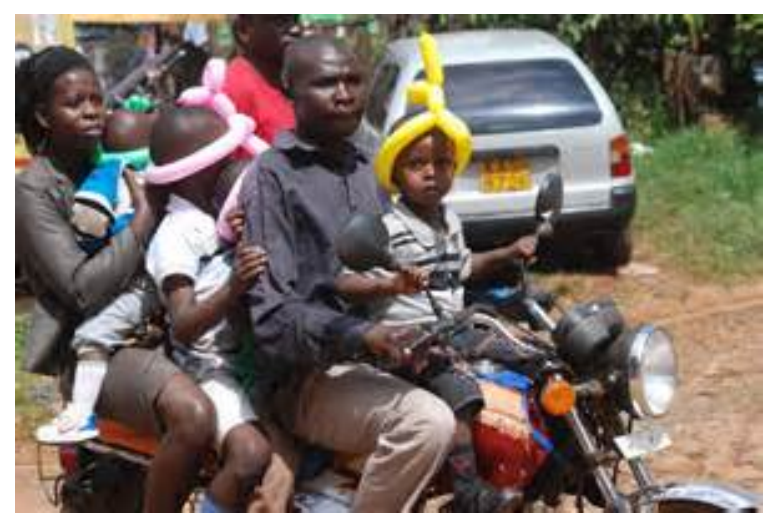

Figure 4. Motor cycle (Boda-boda) rider carrying four passengers in Kampala City

It is also common to hear complaints of people who have lost their land in Uganda. Wakiso district and Kampala city are not spared. Wakiso district surrounding Kampala city faces many land eviction cases. Land is fixed and the population increasing and the expansion of Kampala into Wakiso district aggravate the problem. Those who lose their land vote against the ruling party (NRM). Besigye of FDC is always pulling crowds by telling the voters that he is the one who will save them from the rich people who are taking the land of the poor. He uses the slogans: "You are slaves in your own country" "We want to get power from the few monopolizing it and give it to the majority"

Urban wetlands and forests have particularly come under intense pressure due to the growing urban population and increased socio-economic activities. Namanve Central Forest Reserve; 1,200 hectares, situated in Kira Town Council, Wakiso district is one of the 14 Forest Reserves to be degazetted. The replacement is intended to be approximately 9793 hectares reserved for 8 ranches in Bunyoro (Karugaba [19]). The degazetted land is meant to be given to investors to construct industries. However, the opposition candidates used this to attract the voters by telling them that: "The government is parceling the land to its supporters and foreigners in the name of investors".

Social media favor urban campaigns. While in 2011 there were 940,000 Internet subscribers in Uganda, by 2015 the number had grown to about 7.1 million largely driven by mobile internet subscriptions that had grown by $700 \%$ from 850,000 in 2011 to 6.8 million by the end of 2015. The 18-29 voter's segment in urban and peri-urban areas was where Besigye of FDC backed by DP had the strongest appeal. This is why his supporters were able to take control of the media, a platform that allows multiplication and amplification of messages on an unprecedented scale. Museveni supporters were largely the rural poor, who participate less on social media and therefore, contribute less to public discourse (Mwenda [15]). 


\section{Conclusions}

Wakiso district and Kampala city having the largest concentration of voters has always been a hot spot for political power in Uganda. Due to urban growth outpacing economic growth the opposition has always used the weaknesses of the government and the good policies of the government that affect the poor who are the majority to their advantage. This explains why the opposition led by FDC has in most cases performed better in the urban areas than the ruling NRM during the elections.

\section{Recommendations}

The authors of the paper recommend fast tracking the establishment of Kampala Metropolitan Area to allow the implementation of the Metropolitan Development Plan that will go a long way in solving a number of problems being experienced. Consultative development planning that balances economic and environmental concerns taking into account Sustainable Development Goal number 11 should be emphasized. Development of the urban areas should go hand in hand with conservation and preservation of forests and wetlands. The government should concentrate on urban administrative units for development rather than creation of new districts in the implementation of the decentralization policy.

\section{Acknowledgements}

Thanks to SIDA through the BREAD project for funding this paper that was presented in the $11^{\text {th }}$ International Conference of the African Association of Remote Sensing of the Environment (AARSE): $24^{\text {th }}$ to $28^{\text {th }}$ October 2016, Kampala - Uganda

\section{REFERENCES}

[1] Uganda Bureau of Statistics (UBOS) and ICF. Uganda Demographic and Health Survey, 2016. Key Indicators Report Kampala, Uganda. UBOS, Rockville, Maryland, USA. 2017;

[2] Ggoobi R. Performance of Uganda's economy: progress, opportunities, challenges and way forward. 2016;1-26.

[3] UNFPA. State of Uganda Population Report. Transforming Uganda's economy; Opportunities to harness the Demographic dividend for Sustainable Developement. 2017;
[4] Tumwine FR, Ntozi J. Urbanization fueling marriage dynamics among the Baganda of central Uganda. African Popul Stud [Internet]. 2017 May 30 [cited 2018 Jun 25]; 31(1). Available from:

http://aps.journals.ac.za/pub/article/view/1009

[5] Uganda Bureau of Statistics (UBOS). Uganda Population and Housing Census 2002. Main Report. National Census Office. 2005;

[6] Kaijuka E, Kaija E, Cross A, Loaiza E. Uganda demographic and health survey 2011. Uganda Minist Heal [Internet]. 2011;1-45. Available from: http://ubos.org/onlinefiles/uploads/ubos/pdf documents/Uganda DHS 1988-89 Final Report.pdf

[7] Ministry of Finance and Economic Planning. Uganda Demographic and Health Survey (UDHS) 2000/ 2001. Uganda Bur Stat Stat. 2002;167.

[8] Uganda Bureau of Statistics (UBOS). Statistical Abstract 2014. 2014.

[9] Taubenböck H, Wegmann M, Roth A, Mehl H, Dech S. Urbanization in India - Spatiotemporal analysis using remote sensing data. Comput Environ Urban Syst

[10] T DAM. Sources of Productivity growth in Uganda, The role of Inter Industry and Intra Industry misallocation in 2000s. 2001;

[11] Ha PQ. Managing Vietnamese soils to respond to climate change. Improve soil carbon stock and GHG mitigation in rice production. Fao. 2013;SLM Region(September):17189.

[12] Pham HM, Yamaguchi Y, Bui TQ. A case study on the relation between city planning and urban growth using remote sensing and spatial metrics. Landsc Urban Plan [Internet]. 2011;100(3):223-30.

[13] Kahangirwe P. Linking environmental assessment and rapid urbanization in Kampala City" Impact Assessment and Project Appraisal. 2012;30(2):111-5.

[14] Kwesiga P. Disband district land boards- Probe Report. The New Vision. 2018 Feb;

[15] Mwenda A. Power of social media: How Museveni got $60 \%$ and Besigye won the election. Sunday Vision. The New Vision. 2016 Apr 17;14.

[16] UNFPA. The State of Uganda Population Report 2012. Uganda at 50 years: Population and service delivery; Challenges, opportunities and Prospects. 2012;14-27.

[17] Mugisa A. Traffic jam eats up sgh.2.8 trillion every year. The New Vision. 2017 Jun;31.

[18] Kitubi M, Ssenyonga ALJA\& ML. Police stops eviction as KACITA shuns meeting. The New Vision. 2016 Oct;

[19] Karugaba MOA \&Kashaka U. Government to degazette 14 urban forests reserves. The New Vision. 2016 April; 